Jolanta Adamiec*

\title{
Konkurencyjność polskiego eksportu
}

\begin{abstract}
Competitiveness of Polish exports: The article offers a pragmatic analysis of the Polish exports, with focus on empirical aspects of its competiveness. First, statistical data indicating the position of Polish goods and services in international trade are presented, which also puts into perspective the size of the Polish economy. Next, the comparative advantages of Polish exports, broken down into groups and categories of products, are examined. In the final section the author identifies some factors, such as foreign direct investment, innovativeness and business environment, which can further increase the competitiveness of Polish exports.
\end{abstract}

Słowa kluczowe: konkurencyjność gospodarki narodowej, handel międzynarodowy w Polsce, konkurencyjność polskiego handlu zagranicznego, przewagi komparatywne

Keywords: competiveness of national economy, international trade in Poland, competitiveness of Polish foreign trade, comparative advantages

* Doktor nauk ekonomicznych, specjalista ds. systemu gospodarczego w BAS; e-mail: jolanta.adamiec@sejm.gov.pl.

\section{Wstęp}

Eksport jest istotnym czynnikiem wpływającym na PKB - podstawową miarę zasobności i pozycji państwa w gospodarce światowej. Zatem zdolność danego kraju do wytwarzania dóbr i usług, które w warunkach wolnego handlu znajdują popyt na międzynarodowym rynku, jest postrzegana jako zjawisko bardzo pożądane z punktu widzenia rozwoju gospodarczego. Możliwości zwiększania sprzedaży na rynkach zagranicznych pozostają jednak w ścisłym związku z jakością oferty eksportowej, jej ceną w porównaniu z innymi dostawcami, ale także z trwałością powiązań i unikalnością oferty. Zdolność gospodarki do utrzymania konkurencyjności jest zatem w obszarze handlu zagranicznego w szczególnie wyrazisty sposób poddana weryfikacji. Z tego względu konkurencyjność eksportu jest przedmiotem wielu analiz prowadzonych na różnych poziomach i w różnych kontekstach. 
Celem niniejszego artykułu nie jest jednak przegląd rozmaitych definicji konkurencyjności międzynarodowej ani też teoretyczne analizowanie jej mierników czy porównywanie ich adekwatności i przydatności dla weryfikacji pozycji danego kraju w świecie, lecz praktyczna ocena pozycji Polski na światowym rynku towarów i usług. Oznacza to, że przedmiotem opracowania jest przede wszystkim empiryczne zbadanie pozycji konkurencyjnej Polski na rynku światowym, a w szczególności przyjrzenie się usytuowaniu naszego kraju w porównaniu z innymi państwami członkowskimi Unii Europejskiej (UE), a następnie rozważenie, czy wymaga to zmian, a jeśli tak - to jakich.

Punktem wyjścia jest statystyczne spojrzenie na udział Polski w handlu światowym na tle takich podstawowych wskaźników wielkości danej gospodarki, jak PKB i liczba mieszkańców. W tych porównaniach szczególnie istotne jest usytuowanie Polski w gronie państw należących do UE. Tym kwestiom poświęcona jest pierwsza część opracowania. W dalszej części omówiona została aktualna pozycja konkurencyjna polskiego eksportu, głównie na podstawie analizy ujawnionych przewag komparatywnych i ich zmiany od roku 2000. Dla ich zestawienia wykorzystano metodologię przyjętą przez Bank Światowy i dane zawarte w prowadzonej przez tę instytucję bazie World Integrated Trade Solution.

W ostatniej części artykułu podjęto próbę oceny najważniejszych czynników determinujących pozycję konkurencyjną polskiego eksportu. Wydaje się, że jej korzenie sięgają głębszych struktur polskiej gospodarki, w szczególności zdolności do przyciągania bezpośrednich inwestycji zagranicznych, poziomu innowacyjności oraz warunków prowadzenia działalności gospodarczej. Te aspekty zostały poddane bardziej szczegółowym porównaniom w skali międzynarodowej, a zwłaszcza w odniesieniu do pozostałych krajów członkowskich Unii. Braki w tych obszarach mogą stać się punktem wyjścia dla działań poprawiających pozycję Polski w światowej wymianie handlowej.

W artykule uwzględniono najnowsze możliwe do uzyskania spójne dane statystyczne. Ponieważ nie we wszystkich źródłach dostępne są dane dla 2017 r., a nawet dla 2016 r., to w tych przypadkach wykorzystane statystyki muszą zamykać się na roku 2015. Natomiast jako punkt odniesienia przyjęto rok 2000, gdy dla zobrazowania trendu potrzebny był dłuższy szereg czasowy, lub rok 2010, gdy dla logiki wywodu bardziej przydatne wydawały się ostatnie lata, natomiast zastosowanie dłuższego szeregu czasowego jedynie zaciemniałoby analizę nadmiarem liczb. W niektórych przypadkach natomiast ograniczono się do jednego roku, dla którego dostępne są najbardziej aktualne dane, jeśli porównanie w czasie w danym kontekście nie wydawało się istotne.

\section{Pozycja Polski w handlu międzynarodowym}

Udział Polski w międzynarodowym handlu towarowym (tabela 1) systematycznie rośnie: w 2015 r. wynosił on w światowym imporcie 1,21\%, a w eks- 
porcie $-1,23 \%$, co dawało nam odpowiednio 21 . i 23. miejsce ${ }^{1}$. W porównaniu z globalnym PKB, w którym PKB Polski stanowił w 2015 r. zaledwie 0,73\% (24. miejsce w światowym rankingu), pozornie wydaje się to odpowiadać potencjałowi gospodarczemu. Jednak już przy uwzględnieniu PKB na mieszkańca obraz jest mniej optymistyczny - w 2015 r. dla Polski wskaźnik ten stanowił 171,4\% światowego PKB na osobę, co sytuowało nasz kraj bliżej wyników krajów rozwiniętych gospodarczo (do których zresztą aspirujemy) niż krajów na drodze rozwoju (tabela 2). Zatem udział Polski w wymianie międzynarodowej także powinien odpowiadać możliwościom krajów na wyższym poziomie rozwoju.

Tabela 1. Udział Polski w światowym handlu oraz PKB w latach 2000-2015 (w \%)

\begin{tabular}{|l|c|c|c|c|}
\hline \multicolumn{1}{|c|}{ Kategoria } & $\mathbf{2 0 0 0}$ & $\mathbf{2 0 0 5}$ & $\mathbf{2 0 1 0}$ & $\mathbf{2 0 1 5}$ \\
\hline Import towarów & 0,75 & 0,96 & 1,17 & 1,21 \\
\hline Eksport towarów & 0,50 & 0,86 & 1,06 & 1,23 \\
\hline PKB w cenach bieżących & 0,46 & 0,51 & 0,64 & 0,73 \\
\hline PKB/mieszkańca & 134,5 & 138,0 & 164,3 & 171,4 \\
\hline
\end{tabular}

Źródło: na podstawie „Rocznika Statystyki Międzynarodowej GUS” 2017, tab. I.1 i I.35.

Tabela 2. PKB na mieszkańca w 2015 r.

\begin{tabular}{|l|c|c|}
\hline \multicolumn{1}{|c|}{ Region } & $\begin{array}{c}\text { Ceny bieżące } \\
\text { (w dolarach US) }\end{array}$ & $\begin{array}{c}\text { W stosunku do światowego } \\
\text { PKB (w \%) }\end{array}$ \\
\hline ŚWIAT & 10095 & 100,00 \\
\hline kraje rozwinięte gospodarczo & 41518 & 411,27 \\
\hline kraje rozwijające się gospodarczo & 4902 & 48,56 \\
\hline kraje zmieniające typ gospodarki & 6459 & 63,98 \\
\hline Afryka & 1914 & 18,96 \\
\hline Ameryka Północna, Środkowa i Południowa & 25229 & 249,91 \\
\hline w tym Ameryka Północna & 54767 & 542,52 \\
\hline Australia i Oceania & 37107 & 367,58 \\
\hline Azja & 6036 & 59,79 \\
\hline Europa & 25590 & 253,49 \\
\hline Polska & 12355 & 171,40 \\
\hline
\end{tabular}

Źródło: na podstawie „Rocznika Statystyki Międzynarodowej GUS” 2017, tab. I.1 i I.40.

Szczególnie istotne jest porównanie Polski z pozostałymi państwami członkowskimi Unii Europejskiej (tabela 3). W 2017 r. eksport towarowy z Polski stanowił w handlu zewnętrznym Unii Europejskiej jako całości 2,2\%, a import $3,2 \%$. Od 2011 r. udział ten zwiększył się odpowiednio o 0,3 i 0,6 punktu procentowego, lecz nadal odstawał daleko nie tylko od takich hegemonów, jak Niemcy, Wielka Brytania czy Francja, ale także od krajów znacznie mniejszych niż Polska, jak Belgia czy Holandia. Nawet w zestawieniu z często porównywaną z nami

1 „Rocznik Statystyki Międzynarodowej GUS” 2017, tab. I.2. 
pod wieloma względami Hiszpanią, miejsce Polski wyglądało skromnie - nasz udział był ponaddwukrotnie mniejszy, zarówno w eksporcie, jak i w imporcie zewnętrznym UE. Zatem na tle państw należących do UE Polska zajmowała raczej skromną pozycję, nieadekwatną do rozmiarów naszego kraju.

Tabela 3. Udział poszczególnych krajów członkowskich w eksporcie i imporcie zewnętrznym UE, w latach 2010-2017

\begin{tabular}{|c|c|c|c|c|c|c|}
\hline \multirow{2}{*}{ Kraj } & \multicolumn{3}{|c|}{ Eksport } & \multicolumn{3}{|c|}{ Import } \\
\hline & 2010 & 2014 & 2017 & 2010 & 2014 & 2017 \\
\hline Austria & 2,4 & 2,4 & 2,3 & 1,7 & 1,9 & 1,9 \\
\hline Belgia & 6,1 & 6,1 & 5,7 & 5,9 & 7,1 & 6,9 \\
\hline Bułgaria & 0,4 & 0,5 & 0,5 & 0,5 & 0,6 & 0,6 \\
\hline Chorwacja & 0,3 & 0,2 & 0,3 & 0,4 & 0,2 & 0,3 \\
\hline Cypr & 0,0 & 0,1 & 0,1 & 0,1 & 0,1 & 0,2 \\
\hline Czechy & 1,2 & 1,4 & 1,4 & 1,6 & 1,6 & 1,7 \\
\hline Dania & 1,8 & 1,8 & 1,8 & 1,2 & 1,4 & 1,3 \\
\hline Estonia & 0,2 & 0,2 & 0,2 & 0,1 & 0,1 & 0,2 \\
\hline Finlandia & 1,8 & 1,4 & 1,3 & 1,2 & 1,1 & 0,9 \\
\hline Francja & 11,4 & 10,2 & 10,4 & 9,5 & 9,7 & 9,0 \\
\hline Grecja & 0,7 & 0,8 & 0,7 & 1,6 & 1,5 & 1,3 \\
\hline Hiszpania & 4,4 & 5,2 & 5,1 & 6,6 & 6,8 & 6,8 \\
\hline Holandia & 7,3 & 7,2 & 7,6 & 13,4 & 14,2 & 14,7 \\
\hline Irlandia & 2,8 & 2,4 & 3,2 & 1,1 & 1,2 & 1,5 \\
\hline Litwa & 0,5 & 0,6 & 0,6 & 0,5 & 0,5 & 0,5 \\
\hline Luksemburg & 0,2 & 0,1 & 0,1 & 0,2 & 0,2 & 0,2 \\
\hline Łotwa & 0,2 & 0,2 & 0,2 & 0,1 & 0,2 & 0,2 \\
\hline Malta & 0,1 & 0,1 & 0,1 & 0,1 & 0,1 & 0,1 \\
\hline Niemcy & 27,8 & 28,0 & 28,3 & 19,1 & 18,5 & 18,9 \\
\hline Polska & 1,8 & 2,2 & 2,2 & 2,6 & 3,0 & 3,2 \\
\hline Portugalia & 0,7 & 0,8 & 0,8 & 0,9 & 0,9 & 0,9 \\
\hline Rumunia & 0,8 & 0,9 & 0,8 & 0,8 & 0,9 & 1,0 \\
\hline Słowacja & 0,5 & 0,6 & 0,6 & 0,9 & 0,9 & 0,8 \\
\hline Słowenia & 0,4 & 0,4 & 0,4 & 0,4 & 0,5 & 0,5 \\
\hline Szwecja & 3,8 & 3,0 & 2,9 & 2,3 & 2,3 & 2,1 \\
\hline Węgry & 1,2 & 1,0 & 1,0 & 1,3 & 1,2 & 1,2 \\
\hline Wielka Brytania & 11,7 & 11,6 & 10,9 & 14,6 & 14,4 & 14,8 \\
\hline Włochy & 10,5 & 10,6 & 10,6 & 10,6 & 9,0 & 8,6 \\
\hline Unia Europejska (28 państw) & 100 & 100 & 100 & 100 & 100 & 100 \\
\hline
\end{tabular}

Źródło: baza danych Eurostatu, http://ec.europa.eu/eurostat/data/database [dostęp: 12 czerwca 2018 r.].

Unia Europejska pozostaje naszym głównym partnerem handlowym (tabela 4), zwłaszcza po stronie eksportu, z którego niemal 80\% trafia do państw członkowskich UE. Natomiast zaledwie 7\% polskiego eksportu towarowego kierowane jest do krajów rozwijających się. Taka koncentracja na rynkach dość ograniczonej liczby krajów, których wzrost gospodarczy jest stosunkowo umiarkowany w porównaniu z niezwykle dynamicznym wzrostem niektórych 
państw Azji, Ameryki Południowej czy Afryki, jest pewną słabością polskiego handlu zagranicznego. Dała się ona odczuć chociażby w czasie kryzysu ekonomicznego z 2008 r., kiedy to dekoniunktura u naszych czołowych partnerów handlowych z Unii Europejskiej osłabiła wyraźnie także naszą dynamikę gospodarczą.

Tabela 4. Handel zagraniczny Polski według grup krajów, 2010 r. i 2017 r.

\begin{tabular}{|c|c|c|c|c|}
\hline \multirow[b]{2}{*}{ Grupa krajów } & \multicolumn{2}{|c|}{2010} & \multicolumn{2}{|c|}{2017} \\
\hline & $\begin{array}{c}\text { w mln } \\
\text { dolarów US }\end{array}$ & udział w \% & $\begin{array}{c}\text { w mln } \\
\text { dolarów US }\end{array}$ & udział w \% \\
\hline Import, w tym: & 178063 & 100 & 227774 & 100 \\
\hline UE & 106127 & 59,5 & 136802 & 60,1 \\
\hline pozaeuropejskie kraje rozwinięte & 9397 & 5,3 & 12391 & 5,4 \\
\hline kraje rozwijające się & 37191 & 20,9 & 55740 & 24,5 \\
\hline Eksport, w tym: & 159758 & 100 & 228182 & 100 \\
\hline UE & 126742 & 79,1 & 181891 & 79,7 \\
\hline pozaeuropejskie kraje rozwinięte & 5385 & 3,4 & 10108 & 4,4 \\
\hline kraje rozwijające się & 11195 & 7,8 & 17586 & 7,7 \\
\hline
\end{tabular}

Źródło: baza danych GUS, http://stat.gov.pl/banki-i-bazy-danych/handel-zagraniczny/ [dostęp: 12 czerwca 2018 r.].

Poza UE ważnymi partnerami Polski w obrocie towarowym są Rosja, Stany Zjednoczone i Chiny (tabela 5), aczkolwiek wymiana z tym ostatnim krajem jest wybitnie niezrównoważona i prowadzi do wyjątkowo wysokiego deficytu handlowego. O ile import z Chin w 2017 r. wyniósł ponad 27 mld dolarów US, co stanowiło $11,85 \%$ całości polskiego importu, o tyle eksport na rynek chiński wyniósł nieco ponad 2 mld dolarów US (1,01\% całego eksportu), plasując Chiny dopiero na szóstym miejscu w gronie pozaunijnych odbiorców polskich towarów. Natomiast udział w polskim handlu gospodarek najbardziej dynamicznych, takich jak: Indie, Filipiny, Kambodża czy Wietnam w Azji, bądź Etiopia czy Kenia w Afryce, w których w 2016 r. PKB na głowę wzrósł o 5\% i więcej, lub chociażby państw Azji Centralnej, takich jak: Turkmenistan, Tadżykistan czy Uzbekistan, w których wzrost PKB na głowę przekroczył w 2016 r. 4,5\%, miał całkowicie marginalne znaczenie ${ }^{2}$.

W handlu usługami pozycja Polski jest nawet słabsza niż w handlu towarami. W 2016 r. udział naszego kraju w handlu zewnętrznym UE-28 w obrocie usługowym wynosił 1,62\% w eksporcie i 0,91\% w imporcie, wynosząc odpowiednio: 13,7 mld euro i 6,5 mld euro. Tymczasem - przywoływana wcześniej jako punkt odniesienia - Hiszpania odnotowuje udział na poziomie $5 \%$ w eksporcie usług

2 Dane nt. PKB na podstawie bazy danych Banku Światowego, http://wdi.worldbank. org/tables [dostęp: 12 czerwca 2018 r.]. 


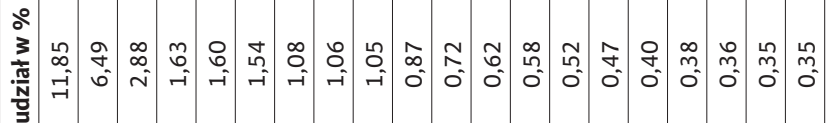

บ

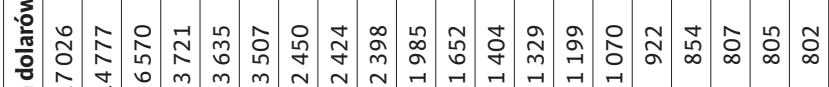
$\frac{c}{\frac{c}{5}}$

蒿

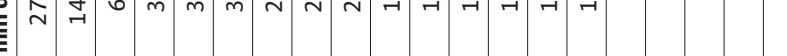

可

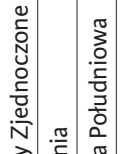

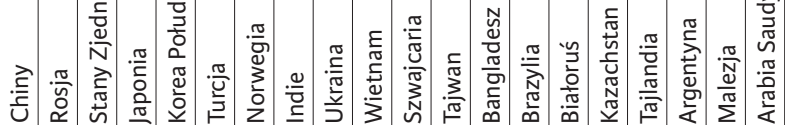

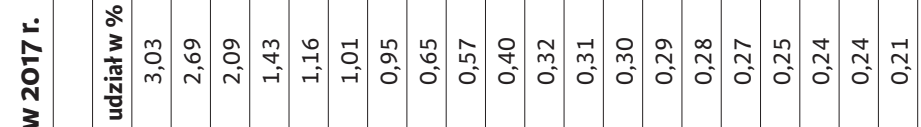

ร)

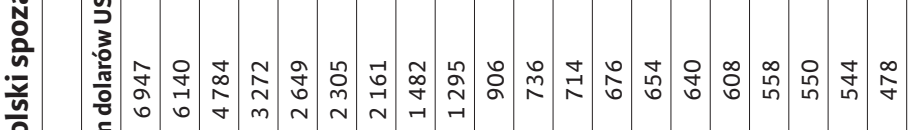

$\stackrel{1}{\circ}$

을

늘

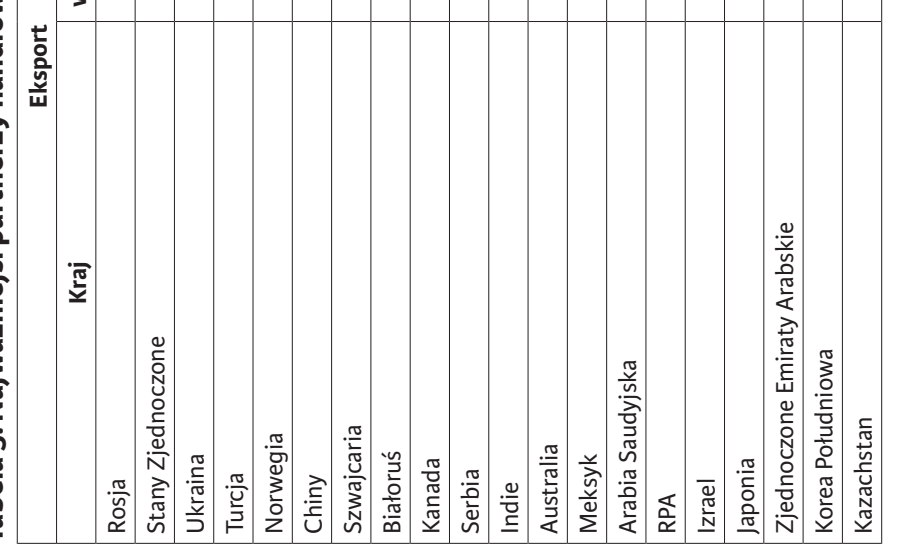

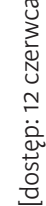

灾

ก. 
poza granice Unii oraz blisko 3\% w imporcie usług'. Przy uwzględnieniu handlu wewnątrzunijnego wartość usług dostarczonych przez Polskę w 2016 r. za granicę wyniosła 45 mld euro, a nabytych usług 30,9 mld euro; podobnie jak w wymianie towarowej najważniejszym naszym partnerem pozostawały Niemcy z wartościami wynoszącymi odpowiednio: 10,5 mld euro i 6,7 mld euro ${ }^{4}$.

\section{Przewagi konkurencyjne w handlu towarami}

Dla oceny międzynarodowej konkurencyjności polskiego handlu zagranicznego istotne znaczenie ma analiza ujawnionych przewag komparatywnych (RCA, Revealed Comparative Advantages) dla poszczególnych grup towarowych (tabela 6). W 2016 r. największe wartości wskaźników odnotowano dla: drewna, przetworów spożywczych i zwierząt żywych (wskaźnik RCA powyżej 2, gdzie wartość powyżej 1 oznacza występowanie przewagi komparatywnej, a poniżej 1 - brak jej brak, a poniżej 1 - brak takiej przewagi), a także dla metali oraz tworzyw sztucznych i kauczuku (wskaźnik RCA na poziomie 1,4). Łącznie te grupy towarowe stanowily 32\% eksportu Polski w 2016 r. Przewaga komparatywna utrzymywała się ponadto w eksporcie sprzętu transportowego (choć w ostatnim okresie uległa osłabieniu) oraz w grupie artykułów przemysłowych różnych (gdzie systematycznie rosła). Pozycje te stanowiły odpowiednio 15\% i 8,7\% eksportu naszego kraju w 2016 r. Łącznie zatem nieco ponad 55\% polskiego eksportu odbywało się w obszarach, w których osiągał on przewagę komparatywną.

Jednak blisko $20 \%$ wywozu realizowane było w grupach towarowych, gdzie ta przewaga nie występowała. Najniższe wartości wskaźników RCA (poniżej 0,7 ) osiągnięto w handlu paliwami, kamieniami i szkłem, materiałami i artykułami włókienniczymi oraz produktami przemysłu chemicznego - ich udział w całości eksportu w 2016 r. wyniósł 15,9\%. Natomiast główna grupa towarowa, stanowiąca blisko $1 / 4$ polskiego eksportu, tzn. maszyny i urządzenia elektryczne, po bardzo nieznacznym przekroczeniu wartości 1 wskaźnika RCA w 2008 r., ponownie odnotowała jego spadek do 0,9 w 2016 r., co oznacza brak trwałej przewagi komparatywnej w tej kategorii.

Zatem z perspektywy osiąganych w handlu międzynarodowym przewag komparatywnych sytuacja Polski nie kształtuje się korzystnie, bowiem niemal połowa eksportu odnotowuje albo brak przewagi komparatywnej, albo wskaźnik ten oscyluje wokół wartości neutralnej. Dążeniem każdego kraju powinno być natomiast czerpanie dochodów z tych kategorii towarów, w których jego działalność wytwórcza osiąga przewagę w porównaniu $\mathrm{z}$ innymi producentami. Pojawia się jednak pytanie, na ile w przypadku Polski należałoby dążyć do

${ }^{3}$ Na podstawie bazy danych Eurostatu, http://ec.europa.eu/eurostat/data/database [dostęp: 12 czerwca 2018 r.].

4 „Rocznik Statystyczny Handlu Zagranicznego GUS” 2017, tab. 32 i 33. 
Tabela 6. Ujawnione przewagi komparatywne (RCA)* i udział w eksporcie głównych grup towarowych w latach 2000-2016

\begin{tabular}{|l|c|c|c|c|c|c|}
\hline \multirow{2}{*}{\multicolumn{1}{c|}{ Grupa towarowa }} & \multicolumn{3}{c|}{$\begin{array}{c}\text { Ujawnione } \\
\text { przewagi komparatywne }\end{array}$} & \multicolumn{3}{c|}{ Udział w eksporcie } \\
\cline { 2 - 7 } & $\mathbf{2 0 0 0}$ & $\mathbf{2 0 0 8}$ & $\mathbf{2 0 1 6}$ & $\mathbf{2 0 0 0}$ & $\mathbf{2 0 0 8}$ & $\mathbf{2 0 1 6}$ \\
\hline Zwierzęta żywe & 1,28 & 2,11 & 2,06 & 2,40 & 3,42 & 4,04 \\
\hline Produkty roślinne & 0,90 & 0,77 & 0,81 & 2,93 & 2,65 & 2,85 \\
\hline Przetwory spożywcze & 1,28 & 1,74 & 2,08 & 3,66 & 4,35 & 6,35 \\
\hline Paliwa & 0,52 & 0,24 & 0,21 & 5,21 & 4,25 & 2,55 \\
\hline Produkty przemysłu chemicznego & 0,69 & 0,68 & 0,70 & 5,34 & 5,79 & 6,99 \\
\hline Tworzywa sztuczne i kauczuk & 1,12 & 1,43 & 1,42 & 4,45 & 5,99 & 7,01 \\
\hline Drewno & 2,00 & 1,99 & 2,18 & 6,98 & 4,83 & 5,27 \\
\hline Materiały i artykuły włókiennicze & 1,58 & 0,70 & 0,65 & 8,57 & 3,14 & 3,76 \\
\hline Kamieńy i szkło & 0,98 & 0,77 & 0,52 & 2,83 & 2,45 & 2,59 \\
\hline Metale & 2,08 & 1,49 & 1,41 & 12,75 & 12,86 & 9,25 \\
\hline Maszyny i urządzenia elektryczne & 0,68 & 1,02 & 0,90 & 20,16 & 24,42 & 24,60 \\
\hline Sprzęt transportowy & 1,12 & 1,51 & 1,26 & 14,51 & 17,26 & 14,98 \\
\hline Artykuły przemysłowe różne & 0,99 & 1,26 & 1,43 & 8,71 & 8,30 & 8,66 \\
\hline tącznie & - & - & - & 98,50 & 99,71 & 98,9 \\
\hline
\end{tabular}

* Wskaźnik RCA jest liczony jako stosunek udziału danej grupy w eksporcie kraju do udziału tego kraju w eksporcie światowym; wartość powyżej 1 oznacza przewagę komparatywną danego kraju w danej grupie towarowej, poniżej 1 - brak takiej przewagi.

Źródło: na podstawie bazy danych Banku Światowego - World Integrated Trade Solution, https://wits. worldbank.org [dostęp: 21 czerwca 2018 r.].

umacniania pozycji w handlu produktami, w których obecnie osiągamy przewagi komparatywne. $\mathrm{W}$ dużej części są to produkty raczej nisko przetworzone lub nieprzetworzone, które dają się dość łatwo zastąpić zaopatrzeniem z innych kierunków, typowe dla krajów na niskim i średnim poziomie rozwoju. Nie gwarantują więc one trwałej pozycji konkurencyjnej naszego kraju w handlu międzynarodowym.

Zapewnić ją może raczej eksport towarów o dużym wkładzie wartości dodanej, pozwalający na indywidualizację oferty i zaangażowanie w wymianę wewnątrzgałęziową. Taka charakterystyka eksportu pozwala na stabilny udział $\mathrm{w}$ procesie produkcji, wiążący się przy tym także $\mathrm{z}$ aktywnością inwestycyjną u potencjalnych partnerów handlowych. Jest to typowa charakterystyka handlu dla krajów uprzemysłowionych, gdzie coraz większego znaczenia nabiera równoległy przepływ komponentów w ramach określonej gałęzi, branży czy też grupy produktów. Skutkuje to w sposób oczywisty zacieśnieniem więzi handlowych pomiędzy poszczególnymi partnerami, bowiem przeniesienie strumieni handlowych w przypadku produktów zaawansowanych technologicznie, stanowiących część składową większej całości, jest znacznie trudniejsze niż zmiana dostawcy surowców, produktów rolno-spożywczych czy prostych wyrobów pracochłonnych gałęzi przemysłu. Tym samym, tego typu wyspecjalizowany handel 
staje się mniej wrażliwy na wahania koniunktury lub pojawienie się na rynku światowym nowych producentów, często z ofertą imitacyjną o niższej jakości.

Pod tym względem struktura eksportu Polski nie kształtuje się korzystnie w 2016 r. największy udział w eksporcie miały dobra konsumpcyjne i to one jako jedyna kategoria - osiągały przewagę komparatywną (tabela 7). Wskaźnik RCA dla tej kategorii wyniósł 1,39, stopniowo się odbudowując po spadku z 1,47 w 2000 r. do 1,34 w 2004 r. Niepokojąca jest natomiast bardzo słaba pozycja dóbr inwestycyjnych, które po pewnym okresie nadrabiania braku przewagi komparatywnej w handlu międzynarodowym (z poziomu RCA wynoszącego 0,65 w 2000 r. do 0,94 w 2012 r.) ponownie odnotowały pogorszenie konkurencyjności i spadek wskaźnika RCA do 0,87 w 2016 r.

Tabela 7. Ujawnione przewagi komparatywne (RCA) i udział w eksporcie towarów sklasyfikowanych wg miejsca w procesie produkcji w latach 2000-2016

\begin{tabular}{|c|c|c|c|c|c|}
\hline & 2000 & 2004 & 2008 & 2012 & 2016 \\
\hline \multicolumn{6}{|l|}{ Surowce } \\
\hline Udział w eksporcie & 7,17 & 7,03 & 5,92 & 6,74 & 6,27 \\
\hline RCA & 0,7 & 0,58 & 0,39 & 0,43 & 0,56 \\
\hline \multicolumn{6}{|l|}{ Półprodukty } \\
\hline Udział w eksporcie & 23,62 & 22,05 & 20,74 & 21,28 & 17,42 \\
\hline RCA & 1,24 & 1,05 & 1,00 & 1,01 & 0,79 \\
\hline \multicolumn{6}{|l|}{ Dobra konsumpcyjne } \\
\hline Udział w eksporcie & 44,58 & 42,88 & 42,79 & 43,65 & 46,28 \\
\hline RCA & 1,47 & 1,34 & 1,37 & 1,38 & 1,39 \\
\hline \multicolumn{6}{|l|}{ Dobra inwestycyjne } \\
\hline Udział w eksporcie & 24,61 & 28,03 & 28,89 & 28,26 & 29,95 \\
\hline RCA & 0,65 & 0,79 & 0,91 & 0,94 & 0,87 \\
\hline
\end{tabular}

Źródło: jak pod tabelą 6.

\section{Uwarunkowania konkurencyjności polskiego eksportu}

Konkurencyjność eksportu jest pochodną poziomu konkurencyjności całej gospodarki, a zatem co do zasady uwarunkowana jest tymi samymi czynnikami. We współczesnej gospodarce do ważnych impulsów oddziałujących na konkurencyjność należą: zasoby ludzkie, produktywność kapitału, stan infrastruktury, poziom innowacyjności, ale również uwarunkowania polityczne, bariery administracyjne i zaawansowanie systemu finansowego. Część z tych czynników oddziałuje jednak mocniej na handel zagraniczny. Wydaje się, że istotne znaczenie mają w tym przypadku przede wszystkim:

- inwestycje zagraniczne, pogłębiające więzi gospodarcze z podmiotami zewnętrznymi wobec Polski i ułatwiające przepływ know-how,

- poziom innowacyjności, wzmacniający udział dóbr intensywnych technologicznie w wymianie handlowej, 
- warunki prowadzenia działalności gospodarczej, ułatwiające ekspansję przedsiębiorstw, także w wymiarze międzynarodowym.

Pod względem napływu bezpośrednich inwestycji zagranicznych Polska od wielu lat pozostaje atrakcyjną lokalizacją, przyciągając najwięcej kapitału w gronie krajów Europy Środkowej (choć należy pamiętać, że w przeliczeniu na mieszkańca pozycja Polski w porównaniu $\mathrm{z}$ tą grupą jest znacznie gorsza niż pokazują to wartości nominalne). W 2017 r. na nasz kraj przypadło 3\% bezpośrednich inwestycji zagranicznych ulokowanych w Europie, podczas gdy do najpopularniejszych europejskich kierunków dla inwestorów zagranicznych należały Wielka Brytania, Niemcy i Francja, na które łącznie przypadła połowa wartości nowych projektów (odpowiednio 18\%, 17\% i 15\%). Atrakcyjność Europy Środkowej, w tym Polski, wynikająca pierwotnie głównie z łatwo dostępnej taniej i wykwalifikowanej siły roboczej, wyraźnie spada wraz ze wzrostem kosztów pracy i nasilającymi się trudnościami ze znalezieniem pracowników. W efekcie kapitał inwestycyjny poszukujący niższych kosztów produkcji przenosi się do takich krajów jak Serbia (wzrost inwestycji w 2017 r. w stosunku do 2016 r. o 157\%), Turcja (wzrost o 66\%) i Rosja (wzrost o 16\%).

Rozwiązaniem powinna być zmiana struktury inwestycji na bardziej wymagające pod względem produktywności i zastosowanej technologii, a tym samym czerpiące z innowacyjnych rozwiązań, dla których konieczna jest odpowiednio zmotywowana i przygotowana merytorycznie kadra. Nie bez powodu to właśnie najwyżej rozwinięte kraje europejskie przyciągają najwięcej projektów inwestycyjnych. Co oczywiste, impulsem nie jest tam duży zasób tanich pracowników. lecz wysoka wartość dodana wynikająca właśnie z wydajności i nowatorskich rozwiązań. Wysoki poziom innowacyjności warunkuje również trwałe przewagi komparatywne w wymianie wewnątrzgałęziowej towarów przemysłowych. Zatem przebudowa struktury eksportu w kierunku dóbr inwestycyjnych i komponentów produkcyjnych wymaga poziomu innowacyjności zbliżonego do wysoko rozwiniętych krajów europejskich.

Niestety, pod tym względem Polska od lat plasuje się znacznie poniżej średniej dla Unii Europejskiej (wykres 1). W 2017 r. znalazła się wprawdzie w gronie tzw. umiarkowanych innowatorów, czyli tych państw członkowskich UE, dla których wskaźnik innowacyjności (SII, Summary Innovation Index) osiągnął wartość pomiędzy 50\% a 100\% średniej unijnej. W praktyce jednak wśród 28 krajów Polska zajęła czwarte miejsce od końca, wyprzedzając jedynie Rumunię, Bułgarię i Węgry. Co więcej, pozycja naszego kraju niewiele się zmieniła w porównaniu z rokiem 2010, kiedy to SII liczony według aktualnej metodologii wynosił także minimalnie ponad 50\% średniej unijnej, co dawało nam pozycję

5 Game changers. EY's Attractiveness Survey Europe. June 2018, https://www.ey.com/gl/ en/issues/business-environment/ey-attractiveness-surveys [dostęp: 2 lipca 2018 r.]. 
porównywalną z Łotwą, a lepszą jedynie od Rumunii, Bułgarii i Litwy. Jeszcze bardziej niepokojący jest fakt, że wskaźnik innowacyjności rośnie wyraźnie w przypadku większości krajów zaliczanych do kategorii silnych innowatorów i liderów innowacji, zatem nasz dystans do tej grupy nieustannie powiększa się.

\section{Wykres 1. Zbiorczy wskaźnik innowacyjności dla krajów Unii Europejskiej, 2017 r.}

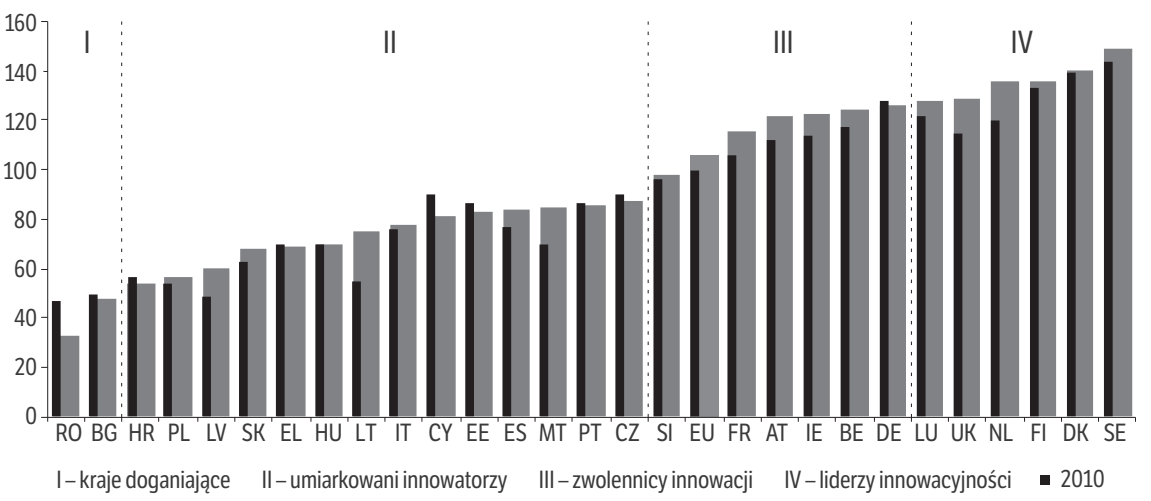

Uwaga: Zbiorczy wskaźnik innowacyjności jest składową 27 wskaźników szczegółowych. Wartości podane na wykresie (lewa kolumna) odnoszą się do średniej dla UE w 2010 r. = 100. Szare kolumny oznaczają poziom osiągnięty przez poszczególne kraje w 2017 r., czarne kolumny oznaczają poziom osiągnięty w 2010 r. Źródło: European Innovation Scoreboard 2018, European Union, 2018.

Warto przyjrzeć się uważniej poziomowi kilku wskaźników szczegółowych uwzględnianych przy kalkulowaniu zbiorczego indeksu (tabela 8). Jedyne komponenty, w których Polska osiągnęła wyniki wyraźnie powyżej średniej unijnej, to: udział ludności z wykształceniem wyższym, zasięg internetu szerokopasmowego, zgłoszenia ochrony wzoru przemysłowego oraz wydatki przedsiębiorstw niemające charakteru badawczo-rozwojowego $(\mathrm{B}+\mathrm{R})$; przy czym ten ostatni wskaźnik pogorszył się w porównaniu z 2010 r. Natomiast pod względem komponentów bezpośrednio odnoszących się do innowacyjności wyniki Polski były zdecydowanie poniżej średniej dla UE. I tak, wydatki na B+R w sektorze publicznym stanowiły mniej niż $1 / 3$ poziomu osiąganego przez Unię jako całość, a, co więcej, wskaźnik ten spadł niemal o połowę w porównaniu z $2010 \mathrm{r}$. Dramatycznie pogorszył się także poziom innowacyjności w małych i średnich przedsiębiorstwach (MŚP): w 2010 r. zbiorczy wskaźnik dotyczący innowacyjnych MŚP wynosił ponad 25\% średniej UE, a w 2017 r. spadł poniżej 3\%, w tym udział przedsiębiorstw wypracowujących własne innowacje - do zera.

Z punktu widzenia konkurencyjności handlu zagranicznego szczególnie istotny jest komponent sprzedażowy wskaźnika innowacyjności. Niestety, pod tym względem wyniki Polski także nie nastrajają optymistycznie. Zbiorczy wskaźnik określany jako „czynniki związane ze sprzedażą” spadł z poziomu 
Tabela 8. Komponenty wskaźnika innowacyjności dla Polski w 2010 r. i w 2017 r.

\begin{tabular}{|c|c|c|}
\hline \multirow[t]{2}{*}{ Nazwa komponentu } & \multicolumn{2}{|c|}{$\begin{array}{l}\text { Wynik Polski jako \% } \\
\text { wyniku UE w } 2010 \text { r. }\end{array}$} \\
\hline & 2010 & 2017 \\
\hline Zasoby ludzkie & 75,1 & 72,2 \\
\hline nowe stopnie doktorskie & 46,2 & 33,3 \\
\hline ludność z wykształceniem wyższym & 140,3 & 147,8 \\
\hline uczenie się przez całe życie & 33,3 & 30,2 \\
\hline Atrakcyjny system badawczy & 21,7 & 33,4 \\
\hline udział w międzynarodowych publikacjach naukowych & 44,0 & 86,4 \\
\hline udział w cytowaniach & 24,9 & 38,7 \\
\hline zagraniczni doktoranci & 9,4 & 7,5 \\
\hline Środowisko sprzyjające innowacyjności & 39,1 & 127,2 \\
\hline zasięg sieci szerokopasmowej & 77,8 & 144,4 \\
\hline skłonność do przedsiębiorczości & 16,2 & 117,0 \\
\hline Finansowanie i wsparcie & 44,6 & 33,2 \\
\hline wydatki badawczo-rozwojowe w sektorze publicznym & 57,5 & 29,2 \\
\hline udział venture capital & 28,0 & 38,2 \\
\hline Skłonność przedsiębiorstw do inwestowania & 72,1 & 90,6 \\
\hline wydatki badawczo-rozwojowe w sektorze przedsiębiorstw & 12,6 & 51,1 \\
\hline wydatki innowacyjne poza badawczo-rozwojowymi & 190,7 & 188,8 \\
\hline firmy szkolące pracowników w technologii informatycznej & 35,7 & 50,0 \\
\hline Innowatorzy & 25,6 & 2,9 \\
\hline innowacje produktowe/procesowe w MŚP & 24,3 & 5,9 \\
\hline innowacje marketingowe/organizacyjne w MŚP & 27,7 & 3,0 \\
\hline MŚP wypracowujące własne innowacje & 24,8 & 0 \\
\hline Powiązania & 47,9 & 37,9 \\
\hline innowacyjne MŚP współpracujące z innymi & 52,1 & 23,0 \\
\hline wspólne publikacje prywatno-publiczne & 34,2 & 36,6 \\
\hline prywatne współfinansowanie publicznych wydatków na B\&R & 58,5 & 54,5 \\
\hline Zasoby intelektualne & 52,0 & 75,2 \\
\hline patenty zgłoszone w międzynarodowym systemie patentowym (PCT) & 9,6 & 18,8 \\
\hline zgłoszenia ochrony znaku towarowego & 50,7 & 80,5 \\
\hline zgłoszenia ochrony wzoru przemysłowego & 92,6 & 124,2 \\
\hline Czynniki związane z zatrudnieniem & 91,6 & 92,5 \\
\hline zatrudnienie na stanowiskach wymagających wiedzy & 42,9 & 59,7 \\
\hline zatrudnienie w przedsiębiorstwach o szybkim wzroście & 126,4 & 115,8 \\
\hline Czynniki związane ze sprzedażą & 67,4 & 55,3 \\
\hline eksport produktów o wysokiej i średniej technologii & 90,4 & 83,9 \\
\hline eksport usług o wysokim wkładzie wiedzy & 45,2 & 45,8 \\
\hline sprzedaż nowości rynkowych/firmowych & 66,2 & 32,7 \\
\hline
\end{tabular}

Źródło: European Innovation Scoreboard 2018, European Union, 2018.

nieco powyżej 67\% średniej unijnej uzyskanego w 2010 r. do zaledwie 55\% w 2017 r., przy czym największy spadek odnotowano pod względem innowacji wprowadzonych na rynek bądź wdrożonych w przedsiębiorstwach. Wprawdzie wskaźnik eksportu usług o wysokim wkładzie wiedzy poprawił się, lecz bardzo 
nieznacznie, bo jedynie o 0,6 punktu procentowego. Natomiast jednocześnie nastąpił niepokojący i dużo wyraźniejszy spadek eksportu towarów o wysokiej i średniej technologii: z $90 \%$ do $84 \%$. Tego typu trendy niestety nie dają nadziei na możliwość zmiany w przewidywalnej przyszłości struktury polskiego handlu zagranicznego na bardziej odpowiadający wysoko rozwiniętej, konkurencyjnej gospodarce.

Pod względem trzeciego z wymienionych wyżej czynników - stabilnych i sprzyjających konkurencyjności warunków prowadzenia działalności gospodarczej - sytuacja Polski wydaje się stosunkowo korzystna. W raporcie Doing Business z 2018 r. ${ }^{6}$ zostaliśmy ulokowani na 27. miejscu na 190 krajów poddanych ocenie. Dało nam to jedenastą pozycję w gronie państw członkowskich Unii Europejskiej za Danią, Wielką Brytanią, Szwecją, Estonią, Finlandią, Litwą, Irlandią, Łotwą, Niemcami i Austrią. Zatem w porównaniu z 2010 r. Polska poprawiła swoją pozycję aż o 45 miejsc, niepokojący jednak jest fakt, że w 2018 r., po długim okresie stopniowego poprawiania pozycji, po raz pierwszy nastąił spadek o 3 miejsca (tabela 9).

Tabela 9. Miejsce Polski w rankingu Banku Światowego Doing Business, w latach 20102018

\begin{tabular}{|c|c|c|c|c|c|c|c|c|c|}
\hline Rok & $\mathbf{2 0 1 0}$ & $\mathbf{2 0 1 1}$ & $\mathbf{2 0 1 2}$ & $\mathbf{2 0 1 3}$ & $\mathbf{2 0 1 4}$ & $\mathbf{2 0 1 5}$ & $\mathbf{2 0 1 6}$ & $\mathbf{2 0 1 7}$ & $\mathbf{2 0 1 8}$ \\
\hline Miejsce Polski & 72 & 70 & 62 & 55 & 45 & 32 & 25 & 24 & 27 \\
\hline
\end{tabular}

Źródło: raporty Doing Business..., World Bank Group, z kolejnych lat.

Najwięcej zastrzeżeń w ocenie dokonanej przez Bank Światowy w odniesieniu do Polski budziła grupa kryteriów dotyczących rozpoczęcia działalności gospodarczej, które obejmują:

- średni czas potrzebny na uruchomienie firmy - wyniósł on $37 \mathrm{dni}$, co daje nam ostatnie miejsce w UE, przy średniej wynoszącej 11,7 dni (w kolejnym za Polską kraju - Słowacji - było to 26,5 dnia, a dla najlepszych czterech krajów: Holandii, Francji, Estonii i Danii było to 3,5 dnia),

- liczba wymaganych procedur - w Polsce koniecznych jest pięć procedur, co dało nam dobrą pozycję na tle innych państw członkowskich UE, dla których było to od trzech (np. Belgia, Szwecja, Estonia) do dziewięciu (Niemcy),

- koszt uruchomienia działalności - został on oszacowany na $12 \%$ dochodu narodowego netto w przeliczeniu na mieszkańca; wśród państw członkowskich UE był to jeden z najwyższych kosztów za Cyprem (12,4\%) i Włochami (13,7\%), podczas gdy dla kolejnej w tej kategorii Malty koszt

${ }^{6}$ Doing Business 2018: Reforming to Create Jobs, World Bank Group, Washington 2018. Dane porównawcze nt. krajów członkowskich UE na podstawie dodatku do raportu głównego pt. Regional Profile - European Union (EU). 
wyniósł 7,3\%, a w zdecydowanej większości państw Unii nie przekraczał 5\%,

- minimalny wymagany kapitał konieczny dla uruchomienia przedsiębiorstwa - wyniósł 10,7\% dochodu narodowego netto w przeliczeniu na mieszkańca, co usytuowało Polskę w połowie rankingu wśród państw UE, choć aż dla $11 \mathrm{z}$ nich wymagany kapitał wynosił zero.

Łącznie wymienione wskaźniki dały w metodologii Banku Światowego ocenę w wysokości 82,78 (w skali od 0 do 100), co pozwoliło na sklasyfikowanie Polski na 120. miejscu na 190 ocenianych krajów. Średnia dla Unii Europejskiej w tej kategorii wyniosła natomiast 90,14, dlatego w tym gronie Polska znalazła się na ostatnim miejscu.

Pozytywnym zaskoczeniem jest natomiast doskonała pozycja Polski pod względem grupy kryteriów odnoszących się do handlu zagranicznego. Już w 2009 r. nasz kraj był pod tym względem blisko średniej unijnej, a w niektórych aspektach odnotowywał nawet nieco lepszy wynik niż średnia dla Unii. W najnowszym raporcie został sklasyfikowany jako lider w tej kategorii i punkt odniesienia dla innych krajów, z łączną wyceną wynoszącą 100 punktów, przy średniej dla UE wynoszącej 97,38 punktów ${ }^{7}$.

Wydaje się zatem, że to nie ułatwienia dotyczące handlu zagranicznego są kluczowe dla uzyskania właściwej pozycji konkurencyjnej w tym sektorze, lecz raczej stworzenie odpowiednich warunków dla prowadzenia działalności gospodarczej. Istotna w tym aspekcie, jak wynika z powyższych danych, jest przy tym łatwość uruchomienia przedsiębiorstwa, $\mathrm{w}$ tym stworzenie warunków dla stymulowania i ochrony inicjatyw innowacyjnych i możliwości przekształcenia ich w stabilny biznes z perspektywą wejścia na rynki zagraniczne.

\section{Podsumowanie}

Udział Polski w wymianie międzynarodowej systematycznie rośnie, lecz tempo tego wzrostu jest na tyle powolne, że nasza pozycja w handlu światowym pozostaje nieadekwatna do potencjału gospodarczego mierzonego chociażby poziomem PKB na jednego mieszkańca. Ten rozziew jest widoczny szczególnie wyraźnie na tle państw członkowskich Unii Europejskiej - choćby w zestawieniu z często porównywaną z nami z uwagi na wielkość kraju Hiszpanią, której udział w handlu zewnętrznym UE jest ponaddwukrotnie wyższy. Ambicjom Polski, jako kraju aspirującego do grona państw rozwiniętych, nie odpowiada

7 Warto jednak zauważyć, że 100 punktów uzyskało także 15 innych państw członkowskich UE. Według kolejności podanej w raporcie są to: Rumunia, Słowacja, Słowenia, Hiszpania, Austria, Belgia, Chorwacja, Czechy, Dania, Francja, Węgry, Włochy, Luksemburg, Holandia i Portugalia. 
także struktura naszego handlu, bowiem pod względem przewag komparatywnych najlepsze wyniki osiągamy w grupach towarowych nisko przetworzonych, jak żywność, drewno czy metale. Jednocześnie blisko połowa eksportu ma miejsce w grupach towarowych, w których przewaga komparatywna Polski nie występuje.

Wypracowanie długoterminowej konkurencyjności w handlu zagranicznym wymaga natomiast oparcia jego struktury na towarach przetworzonych, które nie są łatwe do zastąpienia $\mathrm{z}$ innych źródeł zaopatrzenia, a przy tym na tyle istotnych w procesie produkcji, by wytworzyć trwałe powiązania biznesowe. Dla powstania tego typu międzynarodowych powiązań produkcyjnych i handlowych niewystarczające jest już bazowanie na tradycyjnych czynnikach produkcji, takich jak zasoby naturalne i praca. Konieczne jest sięgnięcie do nowych determinant rozwoju, wśród których dominującą rolę odgrywa wiedza, innowacyjne technologie oraz dynamiczni przedsiębiorcy działający w stabilnym i przyjaznym otoczeniu prawno-instytucjonalnym.

W tych obszarach bilans Polski jest niejednoznaczny. Pod względem napływu bezpośrednich inwestycji zagranicznych Polska od wielu lat pozostaje atrakcyjną lokalizacją, przyciągając najwięcej kapitału w gronie krajów Europy Środkowej. Poza tematem niniejszego artykułu pozostaje analiza struktury tych inwestycji. Jednakże warto zwrócić uwagę na fakt, że gros kapitału inwestycyjnego przyciągają takie państwa członkowskie Unii Europejskiej, jak Wielka Brytania, Niemcy i Francja, za którymi Polska pozostaje daleko w tyle. Udział w międzynarodowych przepływach kapitału ma natomiast istotny wpływ na konkurencyjność eksportu, a zwłaszcza trwałe włączenie w proces produkcyjny i czerpanie z nowoczesnych rozwiązań technologicznych i organizacyjnych. Warto zatem rozważyć, czy przyciągnięcie nowych inwestorów, operujących zaawansowanymi rozwiązaniami produkcyjnymi czy ofertą nowoczesnych usług (np. w kontekście wystąpienia Wielkiej Brytanii z UE) nie byłoby korzystne z punktu widzenia poprawy konkurencyjności polskiego eksportu.

Bardzo negatywny jest natomiast obraz Polski w obszarze innowacyjności. Pod tym względem Polska od lat plasuje się znacznie poniżej średniej dla Unii Europejskiej i notowana jest na końcu rankingów międzynarodowych. Jedyne komponenty z długiej listy składającej się na zbiorczy wskaźnik innowacyjności, w których Polska osiąga wyniki wyraźnie powyżej średniej unijnej, to: udział ludności z wykształceniem wyższym, zasięg internetu szerokopasmowego, zgłoszenia ochrony wzoru przemysłowego oraz wydatki przedsiębiorstw niemające charakteru badawczo-rozwojowego. Natomiast pod względem komponentów realnie budujących bieżącą innowacyjność wyniki Polski są istotnie poniżej średniej dla UE, a szczególnie niepokojąca jest niska skłonność do działań innowacyjnych wśród małych i średnich przedsiębiorstw.

Stosunkowo korzystna jest sytuacja Polski jeśli chodzi o warunki prowadzenia działalności gospodarczej. Wprawdzie w ostatnim roku uległa ona pewnemu 
pogorszeniu, ale w porównaniu z sytuacją sprzed niemal 10 lat skok jakościowy środowiska sprzyjającego przedsiębiorczości jest imponujący. Ten obraz zaciemnia jednak spojrzenie na jeden z istotnych komponentów przedstawionego rankingu, a mianowicie warunki rozpoczęcia działalności gospodarczej. Pod tym względem Polska znalazła się w końcówce ocenianych krajów. Na tle państw członkowskich Unii Europejskiej szczególnie niekorzystnie dla przedsiębiorców kształtuje się czas potrzebny na uruchomienie przedsiębiorstwa oraz związany z tym koszt. Wprawdzie pod względem warunków wymiany z zagranicą Polska należy do liderów, lecz trudności w uruchomieniu działalności w oczywisty sposób ograniczają możliwości ekspansji także w wymiarze międzynarodowym.

Podsumowując, należy stwierdzić, że konkurencyjność naszego handlu zagranicznego nie jest zadowalająca i nie odpowiada potencjałowi kraju na średnim poziomie rozwoju gospodarczego, jakim jest Polska. Jej poprawa nie jest jednak kwestią prostej stymulacji eksportu na nowe rynki, lecz uzależniona jest od bardziej dalekosiężnych zmian ułatwiających działalność gospodarczą (zwłaszcza tworzenie nowych przedsiębiorstw), poprawiających innowacyjność (zarówno poprzez wydatki $\mathrm{B}+\mathrm{R}$ w sektorze publicznym i prywatnym, jak i stymulowanie innowacyjnych rozwiązań w MŚP), a także sprzyjających inwestycjom zagranicznym o bardziej nowatorskim (w tym badawczym), a nie jedynie odtwórczym i pomocniczym charakterze. $W$ wielu tych aspektach osiągamy wyniki gorsze niż inne kraje członkowskie Unii Europejskiej, także nasi najbliżsi sąsiedzi. Dowodzi to istnienia dużego potencjału zmian, które mogą szybko poprawić pozycję konkurencyjną polskiego eksportu.

\section{Bibliografia}

Bieńkowski W. i in., Czynniki i miary międzynarodowej konkurencyjności gospodarek w kontekście globalizacji - wstępne wyniki badań, seria „Prace i Materiały”, nr 284, Instytut Gospodarki Światowej, Oficyna Wydawnicza SGH, Warszawa 2008.

Bouis R., Duval R., Murtin F., The Policy and Institutional Drivers of Economic Growth Across OECD and Non-OCED Economies. New Evidence from Growth Regressions, OECD Economics Department Working Papers 2011, nr 843.

Doing Business 2018: Reforming to Create Jobs, World Bank Group, Washington 2018. European Innovation Scoreboard 2018, European Union, Luxembourg 2018.

Game changers. EY's Attractiveness Survey Europe. June 2018, https://www.ey.com/gl/en/ issues/business-environment/ey-attractiveness-surveys.

Guarascio D., Pianta M., Bogliacino F., Export, R\&D and new products. A model and a test on European industries, Working Papers Series in Economics, Mathematics and Statistics 2014/7, University of Urbino.

Kapitał ludzki i innowacyjność jako czynniki długookresowych przewag konkurencyjnych $w$ handlu międzynarodowym, red. M.A. Weresa, Oficyna Wydawnicza SGH, Warszawa 2013. 
Polska. Raport o konkurencyjności 2017, red. M.A. Weresa, Oficyna Wydawnicza SGH, Warszawa 2017.

„Rocznik Statystyczny Handlu Zagranicznego GUS” 2017.

„Rocznik Statystyki Międzynarodowej GUS” 2017.

Wosiek R., Międzynarodowa konkurencyjność gospodarki - aspekty teoretyczne, „Studia Ekonomiczne. Zeszyty Naukowe Uniwersytetu Ekonomicznego w Katowicach” 2016, nr 269.

\section{Bazy danych}

Bank Światowy, https://wits.worldbank.org.

Eurostat, http://ec.europa.eu/eurostat/data/database.

GUS, http://stat.gov.pl/banki-i-bazy-danych/handel-zagraniczny/. 